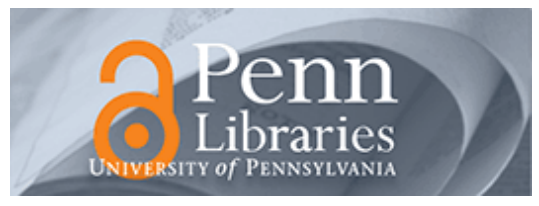

University of Pennsylvania

ScholarlyCommons

Management Papers

Wharton Faculty Research

2016

\title{
Second Thoughts About Second Acts: Gender Differences in Serial Founding Rates
}

Venkat Kuppuswamy

University of North Carolina at Chapel Hill

Ethan Mollick

University of Pennsylvania

Follow this and additional works at: https://repository.upenn.edu/mgmt_papers

Part of the Management Sciences and Quantitative Methods Commons

Recommended Citation

Kuppuswamy, V., \& Mollick, E. (2016). Second Thoughts About Second Acts: Gender Differences in Serial Founding Rates. http://dx.doi.org/10.2139/ssrn.2752689

This paper is posted at ScholarlyCommons. https://repository.upenn.edu/mgmt_papers/177

For more information, please contact repository@pobox.upenn.edu. 


\title{
Second Thoughts About Second Acts: Gender Differences in Serial Founding Rates
}

\author{
Abstract \\ Men are far more likely to start new ventures than women. We argue that one explanation of this gap is \\ that women respond differently to signals of past entrepreneurial success due to the "male hubris, female \\ humility" effect. We argue that as a result women are disproportionately less likely to persist in second \\ founding attempts than men when they have succeeded or failed by large margins. Using a data set of \\ serial founders in crowdfunding, we find evidence supporting this prediction. We then turn to a unique \\ survey of founders in crowdfunding in order to examine alternative explanations. We find support for a \\ variety of systematic differences between male and female founders, but the persistence effect remains. \\ While decreased persistence in the face of low quality opportunities benefits women individually, we \\ argue that it disadvantages women as a group, as it leads to $25.3 \%$ fewer female-led foundings in our \\ sample than would have occurred if women reacted similarly to men.

\section{Disciplines} \\ Management Sciences and Quantitative Methods
}




\title{
Second Thoughts About Second Acts: Gender Differences in Serial Founding Rates*
}

\author{
Venkat Kuppuswamy \\ University of North Carolina at Chapel Hill \\ Ethan Mollick \\ The Wharton School University of Pennsylvania
}

February, 2016

\begin{abstract}
Men are far more likely to start new ventures than women. We argue that one explanation of this gap is that women respond differently to signals of past entrepreneurial success due to the "male hubris, female humility" effect. We argue that as a result women are disproportionately less likely to persist in second founding attempts than men when they have succeeded or failed by large margins. Using a data set of serial founders in crowdfunding, we find evidence supporting this prediction. We then turn to a unique survey of founders in crowdfunding in order to examine alternative explanations. We find support for a variety of systematic differences between male and female founders, but the persistence effect remains. While decreased persistence in the face of low quality opportunities benefits women individually, we argue that it disadvantages women as a group, as it leads to $25.3 \%$ fewer female-led foundings in our sample than would have occurred if women reacted similarly to men.
\end{abstract}

\footnotetext{
* Authorship is alphabetical; both authors contributed equally in developing this paper. The authors would like to thank Adam Cox, Tyler Wry, and Sreedhari Desai for their comments and Derya and Matthew Lane for their help with research. Funding was generously provided by the Kauffman Foundation. All the standard disclaimers apply.
} 
Scholars and policymakers have long expressed concern about a pervasive gender gap in entrepreneurship rates. Women, regardless of culture or nationality, are much less likely to become entrepreneurs than their male counterparts (Bruin et al. 2007, Jennings and Brush 2013, Kelley et al. 2011, Shane 2008). Because of the difficulty of observing nascent entrepreneurs, existing explanations of this gender gap have tended to focus on differential preferences and attitudes towards entrepreneurship between men and women (Bruin et al. 2007, Gupta et al. 2008, Jennings and Brush 2013, Verheul et al. 2012), rather than actual venture initiation. In this paper, we suggest and test a novel mechanism that contributes to gender disparities in founding rates. We draw on research showing that entrepreneurship is driven by the degree to which founder's persist in the face of favorable or unfavorable conditions (Gimeno et al. 1997, Hayward et al. 2006), as well as research on gender differences related to assessments of success (Beyer 1990, Furnham et al. 2002) to suggest that female founders will be less likely to engage in serial entrepreneurship when their first attempts fail, decreasing the likelihood that they become successful entrepreneurs. However, while women are less likely to engage in low quality entrepreneurship in the face of failure, they are also less encouraged than men by prior success, which would result in a reduction in serial entrepreneurial activity associated with high quality opportunities, further decreasing the rate of successful female entrepreneurs. We use a unique dataset of serial founding attempts in the context of crowdfunding to test these effects. In order to address alternative explanations, we use a second dataset, based on extensive surveying, to further explore the reasons why successful female founders have lower serial entrepreneurship rates than men.

In doing so, we add to the growing literature on cognition and entrepreneurship (e.g. Fauchart and Gruber 2011, Grégoire 2010, Hmieleski and Baron 2009, Krueger 2000) in a number of ways. While a founder's expectations in the face of prior failure has long been known to play a role in entrepreneurial decision-making, (Cooper et al. 1995, Dushnitsky 2009) there has been little consideration of cases where a founder may underestimate their own chance of success relative to others. We argue that persistence in the face of both failure and success matter in determining founding rates. Secondly, the paper contributes to the literature by suggesting that systematic differences in entrepreneurial cognition between groups can have large-scale social implications as a result of differential founding rates. We also do so in the context of serial foundings, which are an important 
type of founding behavior (Gompers et al. 2006, Hsu 2007, Paik 2014). Finally, we directly examine mechanisms behind female entrepreneurship rates, where measurement challenges have generally limited inquiries into gender differences in entrepreneurial rates.

Our research design has a number of features that help address these measurement concerns. First, prior studies have not been able to directly examine founding rates from an at-risk population with known characteristics. By studying second founding attempts by crowdfunding project creators, we are able to focus on the differentiating factors between individuals who choose to engage in additional new ventures and those who do not. Additionally, as we have information about failed (and successful) first attempts, we can directly measure the effect of perceived skill on second attempts using the outcomes of prior founding experience. Since founders have direct information about their entrepreneurial ability because of these first attempts, it also reduces concerns about differential knowledge stocks among nascent entrepreneurs. This population is also appropriate because, though successful serial founders differ from novice founders in their likelihood of future success (Gompers et al. 2006, Paik 2014), prior experience does not appear to effect entrepreneurial confidence levels (Ucbasaran et al. 2011). Additionally, by using survey data, we are able to more carefully separate differential persistence rates from other explanations of gendered serial founding differences. This also allows to confirm a variety of prior findings about differentials in founding rates by gender.

We find that women overall are less likely to make second founding attempts than men. Within this general observation, we find a curvilinear effect. Our findings suggest that women are less likely to persist in the face of large-scale failure than men, in that women are proportionately more likely to be discouraged from second attempts when their prior efforts fail by larger margins. We also find strong evidence that successful female founders are proportionately less likely to make second founding attempts than successful men as the level of success grows, even when the range of expected other concerns are addressed. Finally, we consider the population-level impact of these effects, showing that these factors have large-scale policy implications. 


\section{THEORY}

PRIOR LITERATURE ON GENDER DIFFERENCES IN FOUNDING RATES

That there is a gap in entrepreneurship rates between men and women has been definitively established (see Lerner, Brush, \& Hisrich, 1997; Minniti, 2009). In fact, a Global Entrepreneurship Monitor Report found that, of 59 countries, the only one with more female entrepreneurs than men was Ghana (Kelley et al. 2011). Shane (2008, p. 125) sums up these findings as follows: "the reality in the United States today is that women are so much less likely than men to start their own business that if the only thing you know about a person is his or her gender, you can predict whether or not he or she is an entrepreneur with greater accuracy than if you use all of the psychological tests that identify entrepreneurs." It has been argued that this gap in founding rates is a major cause of gender inequality in labor markets (Thébaud 2015).

A variety of mechanisms have been proposed that might help explain some of the reasons for the relative lack of female entrepreneurs. Later in the paper, we directly test some of these mechanisms, as entrepreneurial action is multi-causal in nature. However, previous explanations tend to focus on only a limited portion of the entrepreneurial process, and are therefore relatively distant from both key founding events and the focus of much of the entrepreneurship literature. Generally, they seek to explain either differential preferences for entrepreneurship that might later lead to differences in founding rates, or else they examine structural barriers either those that women might encounter after deciding to be entrepreneurs or else institutional barriers that decrease the ability of women to found businesses.

The literature on post-founding structural barriers has demonstrated, for example, that women receive far less venture financing then men (Canning et al. 2012, Greene et al. 2001, Harrison and Mason 2007). This relative discrimination could be based on taste (Marom et al. 2014), but may stem from network structures that exclude women, based on homophilous ties between (mostly male) funders and male entrepreneurs (Greenberg and Mollick 2015, Stuart and Sorenson 2008). Regardless of cause, this literature focuses on the growth and development of new ventures, rather than an initial decision to enter entrepreneurship. As Shane (2008) argues, there is no evidence to suggest that potential future barriers to financing suppress early-stage startup activity. 
Thus post-founding structural barriers lower the number of successful female entrepreneurs, but not necessarily by decreasing overall founding rates.

Other literature on structural barriers focuses on institutional factors that may either push women to become entrepreneurs, or else lower their ability to enter entrepreneurship. Work-family conflict can force women into low quality founding attempts when full-time work cannot be balanced with family obligations (Heilman and Chen 2003, Thébaud 2015). On the other hand, factors such as subsidized child care can lower entrepreneurship rates for women but allow those women who do become founders to pursue more intensive high-growth enterprises (Thébaud 2015). These factors play an important role in determining cross-national differences in entrepreneurship rates, but do not address the role of differences at the individual level in founding rates.

Outside of structural barriers, the second major stream of research on the entrepreneurship gap examines differential tastes for entrepreneurship among men and women. These primarily rely on surveys of attitudes, and have found repeatedly that women express a lower preference for self-employment than men (e.g. Gupta et al., 2008; Shane, 2008). Some of these preference differences appear to stem from gender stereotypes associated with entrepreneurship, or from differing impressions of entrepreneurship among men and women (Gupta et al. 2008, Jennings and Brush 2013, Kelley et al. 2011, Manolova et al. 2008). Preferences may also be shaped by perceptual differences among women and men in how they perceive and evaluate opportunities (Arenius and Minniti 2005) or social expectations (Jennings and Brush 2013).

Clearly, these preference differences are important, but they offer, at best, a partial and unsatisfying answer to the overall gender gap in founding rates. They are only a partial answer because it is unclear how general preference differences actually effect founding rates. Further, studies of preferences suggest that other factors may be important in explaining gaps in founding rates (Verheul et al. 2012). Preference research focuses only on the very earliest possible stages of the entrepreneurial process - before an opportunity is recognized or created (Shane and Venkataraman 2000). 
Further, the preference explanation is unsatisfying because it does not engage with the core theories of entrepreneurial research, such as opportunity identification (Shane and Venkataraman 2000) and the role of risk and uncertainty (Knight 1921, McMullen et al. 2006). This disconnect is problematic because it tends to separate the study of gender and entrepreneurial rates from the mainstream entrepreneurial literature. Indeed, a "dare" proposed by Jennings and Brush (2013) in their review of the literature on female entrepreneurship is for scholars to better understand the relationship between gender and the identification and exploitation of opportunities.

\section{PERSISTENCE AND THE FOUNDING GAP}

We respond to this "dare" by arguing that the puzzle of why women are less likely to form new ventures can be understood in terms of persistence in entrepreneurial attempts relative to men. This can be viewed as a part of a larger question of considerable scholarly interest (see, for example, Lowe \& Ziedonis, 2006; Simon, Houghton, \& Aquino, 2000): given the high failure rate of entrepreneurship, why does anyone choose to become an entrepreneur? The consensus solution to this problem is that many entrepreneurs are too confident of their success in a variety of ways (Busenitz and Barney 1997, Camerer and Lovallo 1999, Cassar 2010, Dushnitsky 2009, Hmieleski and Baron 2009). That is, entrepreneurs understand that there is risk in any venture, but also overestimate their personal chances of success at all stages of the business (Cassar 2010).

While it has roots in Knightian perspectives of entrepreneurial uncertainty (Gregoire et al. 2009, Knight 1921), a variety of scholarship has focused on unwarranted persistence as a key factor in explaining why people form new ventures in the face of frequent failure (Gimeno et al. 1997, Hayward et al. 2006). Haywood, Sheppard, and Griffin (2006) identify several forms of overconfidence which, collectively, lead entrepreneurs to overestimate their chances of success and thus increase the chances of long-term failure. Follow-up studies have confirmed that unwarranted confidence can lead to negative performance impacts (Hmieleski and Baron 2009). Unwarranted persistence in founding attempts therefore increase the number of venture foundings, but lowers average venture performance.

This type of persistence leads to founding attempts when the chance of success is low, but it is not the only way in which levels of persistence might affect founding decisions. Persistence in an entrepreneurial venture grounded on past entrepreneurial or vocational performance is generally viewed as advantageous. Based on prior 
experience, entrepreneurs are better able to identify opportunities, as well as forecast and plan for successful new ventures (Baron and Ensley 2006, McGrath and MacMillan 2000, Shane 2000). Though success may lead to irrational confidence in the short term, with further experience assessments become more accurate (Gervais and Odean 2001). So, while unwarranted persistence leads to more high-risk and low-quality ventures, persistence with appropriate experience and evidence of potential success should lead to more successful founding.

The degree of persistence in the face of positive and negative signals are important to the question of founding rates because they appear to vary greatly by gender. The "male hubris, female humility" effect has been repeatedly identified in many studies and contexts: men consistently overestimate their own abilities while women consistently underestimate theirs (Beyer and Bowden 1997, Beyer 1990, 1998, Cross and Madson 1997, Furnham et al. 2002). These findings have been shown to be "universal" across multiple cultures (Furnham et al. 2002). While many studies have focused on self-assessment of IQ or other intelligence measures (Beyer and Bowden 1997, Beyer 1990, Furnham 2001, Furnham et al. 2002), similar effects have been observed in work performance reviews and many other domains (Beyer 1990, Beyer et al. 2003, Blanch et al. 2008). This difference seems to stem, in part, from social pressure for female modesty (Furnham et al. 2002), coupled with a lower self-attribution bias among women, in that they are less likely to falsely attribute their success to their own efforts (Beyer 1990, Miller and Ross 1975).

Given the key role self-assessments of success play in determining persistence and founding rates, these gender differences immediately suggest potential implications for the founding gap. If women are less likely to overestimate their chance of success and persist in the face of failure, they should found fewer ventures than men when the chance of success is low. And, if women are less likely to positively assess their chances of success when signal quality is high, then they should found fewer ventures than men when the chance of success is high. In order to develop these concepts further, and to hypothesize about these results, we introduce a research context that allows the first direct gender comparisons of actual venture initiation rates while allowing for reasonable measures of the venture success. 


\section{CONTEXT}

Serial entrepreneurship is a common phenomenon, and one of interest to scholars (Eggers and Song 2015, MacMillan 1986, Paik 2014). Serial entrepreneurship is an important form of persistence - the launching of a new venture after the conclusion of a prior one (Gompers et al. 2006). From an empirical perspective, it also has advantages for measuring the degree to which an entrepreneur's decision to persist is wise, since we can observe behavior of entrepreneurs who have some prior knowledge of their ability to successfully launch a new venture. As a further advantage, serial entrepreneurs would also be able to observe other

In order to locate a population of potential serial founders, we turn to crowdfunding. Crowdfunding is a relatively novel method of raising funds to support a variety of projects and ventures by asking for small donations from a large number of individuals over the internet (Agrawal et al. 2013, Mollick 2014). Successful crowdfunding requires that a project creator convince others to provide money to back a project, sometimes in return for a product or service. This can involve substantial investment of time, money, and social capital on behalf of the project creator. Additionally, it involves a long-term commitment from project creators to fulfill project requirements. Initiating a crowdfunding project is an entrepreneurial endeavor, and, indeed, $90 \%$ of large crowdfunding projects in technology, videogames, and product design turn into ongoing businesses (Mollick and Kuppuswamy 2014).

On the largest crowdfunding platform, Kickstarter, with over $\$ 1 \mathrm{~B}$ in distributed funding, project creators must set a goal - a dollar amount they need to raise in order to successfully complete their project. Failing to reach the goal means that the creator receives no funds at all. On the other hand, projects that meet or exceed their goals keep all of the money they raised. A failure to raise money is a public repudiation of an individual's ability to found a new venture, while a roaring success is a similarly public acclamation that an individual was able to launch successfully.

By examining the amount of money that project founders received in first founding attempts, we can directly consider the degree to which a second project founding attempt is a reasonable or unreasonable proposition. The higher the degree of failure, the more unjustified a second founding attempt is, in general, as the entrepreneur has received a signal about their actual ability to succeed. On the other hand, the higher the 
degree of success, the more past performance suggests that a second founding attempt is likely to succeed. While the degree to which founders learn from prior attempts depends on the similarity of context (Eggers and Song 2015), there is some degree of consistency in the fact that all attempts are on the same crowdfunding platform. Unjustified persistence, therefore, is the founding of a new project in the face of past failure, while justifiable persistence is the founding of a project after a success.

\section{HYPOTHESES}

Recall that women have been found to have lower rates of confidence in the face of low-quality signals than men. We argue that this can help explain some of the founding gap between women and men. Unjustified persistence increases entrepreneurial entry because founders believe they can succeed in the face of evidence.

Men are generally viewed as suffering from higher levels of unjustified confidence then women (Deaux and Emswiller 1974, Nieva and Gutek 1980), this is especially true if a task is considered to be "masculine" such as finance (Barber and Odean 2001) or entrepreneurship (Gupta et al. 2014). In the context of entrepreneurship, self-assessments of entrepreneurial ability, one way of measuring self-confidence, have similarly shown that men are more confident in their founding abilities than women (Thébaud 2010). If women suffer less from unjustified persistence in the face of low-quality signals than men, then they should be (justifiably) less willing to engage in founding activity in the face of previous failure. That suggests that:

H1: Women are less likely than men to engage in second founding attempts after a failure.

If a relative lack of persistence in the face of prior failure explains lower female founding rates, the effect should be moderated by the degree of previous failure. As evidence of past failure increases, persistence in entrepreneurship is less and less justified. A second founding attempt after a project that failed by $\$ 10,000$ is harder to rationalize than a second founding attempt after a project narrowly failed by $\$ 100$. Therefore, women should be more discouraged by severe failure than moderate failure. We therefore hypothesize:

H2: The relative likelihood of female founders to make second founding attempts compared to men is negatively moderated by the degree of failure 
The "male hubris, female humility effect" suggests that, in addition to lower rates of unjustified confidence, women also have lower rates of confidence when faced with high quality signals (Beyer 1990, Furnham et al. 2002). In the case of the male hubris, female humility effect, women are not accurately selfassessing their chances of success, rather they are being humble in the classical sense - modest about their own abilities or success.

There has been evidence of female humility even in the realm of entrepreneurship. For example, women who actually engage in entrepreneurial activities are still less likely to consider themselves entrepreneurs than men with similar levels of experience (Verheul et al. 2005). Women also have lower levels of self-efficacy and confidence in their own entrepreneurial skills, even at similar levels of training to men (Minniti 2009, Thébaud 2010). Thus, it is reasonable to expect that general findings about female humility will hold in the realm of entrepreneurship as well. In that case, women would be less likely to interpret objectively positive signs of past performance as strong signals of their own entrepreneurial ability. We therefore hypothesize:

H3: Women are less likely than men to engage in second founding attempts after a success.

Again, we would expect a moderating effect. At moderate levels of success, women would have lower self-perceptions of their own ability than men, but the impact would grow more apparent as the degree of first project success increased. At very high levels of success, men who are not burdened with humility would attribute their success mostly to ability, while women would be more reluctant to make this connection. This suggests:

H4 The relative likelihood of female founders to make second founding attempts compared to men is negatively moderated by the degree of success

Note that, taken together, our hypotheses imply that the overall gap between male and female entrepreneurs would be inverse V-shaped. Unlike an inverse-U that results from a quadratic (Haans et al. 2015), this effect is the result of two separate mechanisms operating at either side of the origin, the point where a project raises exactly as much as requested. At lower levels of success, men are more likely to persist because they do not respond to signals about the relatively low quality of their first attempts, and women are less likely to engage in a second founding attempt because they have a more realistic assessment of their past success. At higher levels, 
it is men who are more realistic, with lower rates of founding being driven by irrational modesty. While we do not formally hypothesize which of these factors is more important, we will examine this issue. In order to test our hypotheses and examine female founding rates, we turn to our data on crowdfunding.

\section{METHODS}

\section{DATA}

As noted earlier, we use crowdfunding as our empirical setting to explore the role of gender in serial entrepreneurship. Crowdfunding represents an ideal context in this regard due to its increasing importance as a source of early stage seed capital for entrepreneurs, and our ability to extract archival data on the details of multiple entrepreneurial attempts made by individuals over time. Particularly important for our study is the fact that we can observe the attributes of an initial entrepreneurial initiative for a large sample of individuals, measure its performance, and subsequently observe whether the same individual sought to pursue another project on the platform again in the future. Our sample consists of crowdfunding projects posted on Kickstarter, the largest and most prominent crowdfunding platform in the world, as archived by Kickspy, a data aggregation service. More specifically, the entire archive of Kickstarter projects consists of 189,945 projects posted by 162,128 distinct creators from April 2009 to the end of November 2014. Project creators may include informal entities such as an individual or team of individuals, or a formal entity as identified by a company name.

We take several steps to filter the entire archive of projects to arrive at the sample used for our analysis. First, since we are focused on the factors that influence individuals to transition from one-time entrepreneurs to serial entrepreneurs, we limit our focus to the first and second projects (if launched) of Kickstarter creators (which represents $95.4 \%$ of the original dataset). Secondly, as we are concerned with the determinants of repeat

founding behavior, we eliminate creators from our sample who cancelled a crowdfunding attempt in their first or second project. Cancelled projects represent projects that were launched by the creator, but that were terminated before the end of the fundraising process. Cancelled projects represent ambiguous attempts at entrepreneurship and therefore we remove creators with cancelled from our sample. Of the 162,128 creators in the sample, 14,506 creators cancelled a project in their first two attempts (of these, 93\% cancelled their first attempt), leaving 147,622 creators in the sample. 
We also needed to identify the gender of the project creators. On Kickstarter, each project webpage lists the name of the primary creator associated with it, which may either be an individual's name or, in some cases, a group or organization name. In order to determine the gender of the creator, we follow prior work and use genderize.io, an online API that predicts the gender of a first name, along with a corresponding probability associated with the prediction (Greenberg and Mollick 2015). Of the 147,622 creators in the sample, we obtained gender predictions associated with 120,462 of them (81.6\% of the sample), with many of the rest representing collective or company names. Of these 120,462 creators with gender predictions, $67.2 \%$ were men and $32.8 \%$ were female. To reduce bias from our measure of gender, we further restrict or sample to the 104,294 creators whose gender were determined with a probability of 0.9 or greater ${ }^{1}$ (30.3\% of creators are now female). Consistent with prior work on crowdfunding (Mollick 2014), we also enforce a minimum project goal of $\$ 1,000$ so that we only consider non-trivial attempts at entrepreneurship (92,653 creators i.e., $88.8 \%$ of the 104,294 creators with accurate gender values) ${ }^{2}$.

Our final two filters were instituted to ensure that repeat crowdfunding behavior in our sample represent meaningful attempts at serial founding attempts. Crowdfunding on Kickstarter is an all-or-nothing endeavor, where creators who fall short of their fundraising goal receive nothing regardless of how much they raised. As a result, it is not uncommon for creators who fall short to re-launch the same project with a new fundraising goal set at or below what they did raise in their first attempt. They do so to seek those funds committed earlier from supporters who are likely to pledge again. These "money-grab" second attempts do not represent instances of serial entrepreneurship where the first project is modified in some meaningful way or when a fresh new idea is pursued. As a result we drop those creators who pursued money-grab attempts from our sample. We do so by identifying cases where project creators failed in their first project and launched a second project where the funding goal was equal to or below the dollars pledged in the first attempt. Of the 92,653 creators at this stage of the sample, 859 creators $(<1 \%)$ pursued a money-grab and were removed, leaving 91,794 creators. Finally,

\footnotetext{
${ }^{1}$ Our results are robust to relaxing this conservative restriction and allowing all creators with gender predictions in the sample.

${ }^{2}$ Results remain robust at a $\$ 5,000$ threshold as well.
} 
we remove $691(<1 \%)$ project creators who launched a second project before the end of the fundraising period of the first project. These few cases again represent ambiguous attempts at serial foundings, and may also reflect attempts to quickly re-launch a doomed first attempt. In the end, our sample consists of the first projects of 91,054 project creators on Kickstarter ${ }^{3}$.

\section{VARIABLES}

\section{Dependent VARIABLE}

The dependent variable Second Attempt is a binary indicator for whether the creator launched another crowdfunding project after the first attempt. Second Attempt takes the value 1 if the creator does indeed launch another project in the future, and 0 otherwise. Summary statistics of our main variables are displayed in Table 1. From Table 1, we see the mean value of Second Attempt is 0.084 indicating that $8.4 \%$ of first time creators in our sample choose to launch another project in the future. While the data is right-censored, are results are robust to multiple date ranges within the sample.

\section{INDEPENDENT VARIABLES}

The main independent variable in our analysis is Female Creator, a binary indicator taking the value 1 if the primary creator of the project was a woman, and 0 if the primary creator was male. Of the 91,054 creators in our sample, $30 \%$ are women and $70 \%$ are men (the mean value of Female Creator is 0.301 ).

In addition to analyzing the direct effect of gender on launching a second project, we also explore whether the performance of the first project moderates this relationship. We use three separate measures of project performance. First, given the all-or-nothing nature of fundraising on Kickstarter, we define Project Funded to denote whether the project was successful in reaching its fundraising goal $(=1)$ or not $(=0)$. In the case of failed attempts (Project Funded $=0$ ), we define Shortfall to measure the absolute extent to which the creator fell short of his or her goal. Specifically, Shortfall is the goal of the project minus the funds raised in the losing effort. Similarly, in the case of successful attempts (Project Funded = 1), we define Surplus to measure the absolute extent to which the creator exceeded his or her goal. Surplus is the total funds raised by the successful project minus

\footnotetext{
349 of the 91,103 projects in our sample had incorrect or missing word counts related to the description of the project on its webpage, and were dropped from the sample.
} 
goal of the project. Our models also include controls for several attributes of the first project, including its goal size (Goal), the number of reward levels posted to incentivize contributions (Reward Levels), the number of words used to describe the project (Words), the presence of a video as part of the pitch (Video), as well as fixed effects for the category, month, and year associated with the project. As is clear in Table 1, all our continuous variables are highly skewed to the right and therefore, we windsorize them at their $99^{\text {th }}$ percentiles. As we expect diminishing returns to the effect of these variables over their range of values, we follow recent advice on modeling curvilinear relationships and $\log$ transform these variables when we include them in our empirical models (Haans et al. 2015).

\section{[Insert Table 1]}

\section{ESTIMATION METHOD}

In order examine the relationship between creator gender and the likelihood of launching another project; we use a logit estimator to model our binary outcome, Second Attempt, as a function of Female Creator. In order to explore the potential moderating effects of project performance on the relationship between Second Attempt and Female Creator, we also examine models where Female Creator is interacted with a performance variable of interest. However, as is well-documented in prior work on non-linear models, "the interaction effect, which is often the variable of interest in applied econometrics, cannot be evaluated simply by looking at the sign, magnitude, or statistical significance of the coefficient on the interaction term when the model is nonlinear" (Ai and Norton 2003). Instead, the recommended approach that we follow is to compute the marginal effects of Female Creator over the range of the moderating variable and to compare the marginal effects (Ai and Norton 2003, Karaca-Mandic et al. 2012).

\section{[nsert Table 2]}

Moreover, to ensure that any effects are not driven by systematic differences in project characteristics between men and women, we use matched samples of first projects launched by men and women using propensity score matching (Rosenbaum and Rubin 1983, Rosenbaum 2002). We create separate matched samples for the different subsamples used in our analyses - one for all first projects, a matched sample of unsuccessful 
first projects, and lastly a matched sample of successful first projects (see Table 2). More specifically, we use a combination of nearest neighbor matching and caliper matching to generate our matched samples. In nearest neighbor matching, each treatment (female creator) observation is matched with one or more control (male creator) observations that are closest to it in terms of the probability of treatment. The probability of treatment i.e., the project having a female creator, is modeled using a logit where the independent variables are the various project characteristics outlined in Table 2, including binary indicators for the category and launch period of the project. When there are a large number of control observations for each treatment observation, it is recommended to oversample i.e., to use multiple nearest neighbors, to ensure higher efficiency and precision to estimates and to reduce bias from sampling variability (Caliendo and Kopeinig 2008; Stuart and Rubin 2008). We choose 4 nearest neighbor matches for each treatment observation. Nevertheless, our results are quite similar when we either increase or decrease the number of matches chosen for our matched samples. Furthermore, in order to ensure that all matches are of high quality, we impose a tolerance level of 0.01 on the maximum propensity score distance (caliper) allowed between match and treatment observations (Caliendo and Kopeinig 2008). The results of this matching process are displayed in Table 2. We see that the mean of most variables differed between men and women in each unmatched sample (Panels A, B, and C of Table 2). However our matched samples of male and female projects look a lot more similar along these variables. T-tests are largely insignificant, indicating that each matched sample of first projects launched by men and women look very similar along these dimensions. We rely on these matched samples in our subsequent analyses.

\section{RESULTS}

We begin our analysis by examining whether women are overall less likely than men to engage in second founding attempts, and we then evaluate whether this continues to be the case after both an initial failure (H1) and success (H3). As a result, we first test whether Female Creator has a negative effect overall on making a Second Attempt and we then explore whether this relationship is moderated by whether the project succeeded or not (Project Funded). Table 3a presents the results of this analysis using the matched sample of all first projects (Panel A of Table 2). Model (1) is our base model with only controls variables included. While not a focus of our study, we do note that several control variables associated with a creator's first project are significant predictors of 
launching a second attempt. We find that successful projects (Project Funded) and those who pursued projects with smaller goals $(\log ($ Goal) $)$ are more likely to lead to second attempts. Similarly, projects with a video (Video) are less likely to be followed up by another project.

[Insert Tables 3a and 3b]

In Model (2) of Table 3a, Female Creator is now included in the specification. We see that Female Creator has a negative coefficient that is significant at the 1\% level. As a result, across successful and unsuccessful projects, female creators are significantly less likely than men to launch a second attempt on average. In Model (3), we include an interaction term between Female Creator and Project Funded to evaluate the moderating role of overall success on the effect of creator gender. As we highlighted earlier, we cannot directly interpret the sign or the significance of an interaction term in a logit model (Ai and Norton 2003). As a result, we use the results of Model (3) to compute the marginal effect of Female Creator separately for successful (Project Funded $=1$ ) and unsuccessful (Project Funded $=0$ ) projects. These marginal effects are tabulated in Table 3b. We find that the marginal effect of Female Creator is negative and significant (at the 1\% level) for both successful and unsuccessful creators. Therefore, we have supporting evidence for both $\mathrm{H} 1$ and $\mathrm{H} 3$ - women are less likely than men to engage in second founding attempts after both a failure and after a success. This suggests that women have lower levels of persistence in the face of both high and low quality signals.

In the next analysis, we limit the sample to unsuccessful projects and explore how the magnitude of failure may affect the relative likelihood of women launching another project in the future, as predicted in $\mathrm{H} 2$. Table $4 \mathrm{a}$ displays the results of this analysis using the corresponding matched sample of unsuccessful projects (Panel B of Table 2). As before, Model (1) is the base model with only control variables included in the specification. We see that $\log ($ Shortfall) has a positive coefficient, significant at the $1 \%$ level. As a result, creators of larger failures in absolute dollar terms are more motivated to launch another attempt on average. Model (2) includes Female Creator as a covariate, and Model (3) further includes the interaction term between Female Creator and $\log ($ Shorffall). As before, in order to identify whether the magnitude of failure influences the effect of creator gender on launching a second project; we use Model (3) to compute the marginal effect of Female Creator across 
a range of values for $\log ($ Shortfall). These marginal effects for Female Creator are displayed in Table 4b (and illustrated in Figure 1). We find that as Log(Shortfall) increases in value, the marginal effect of Female Creator becomes progressively more negative at a statistically significant level. Therefore, in support of $\mathrm{H} 2$ and our argument about the relatively higher persistence of men in the face of failure, we find that the relative likelihood of women launching another project compared to men is negatively moderated by the size of the failure.

[Insert Tables 4a and 4b]

We now shift our focus to successful creators in order to determine whether the degree of success also negatively moderates the relative effect of female creators pursuing second attempts, as predicted by our humility argument in H4. Table 5a presents the results of logit models for Second Attempt when the sample is limited to our matched sample of successful projects. We first note that $\log ($ Surplus $)$ has a positive and significant, indicating that individuals with higher degrees of success past their goal are more likely to launch again in the future. When we interact Female Creator with $\log ($ Surplus) in Model (3), and compute marginal effects for Female Creator across the range of $\log ($ Surplus) (Table $5 \mathrm{~b}$ ), we do find evidence of a negative moderating effect. Specifically, we find that the marginal effect of Female Creator grows more negative as the value of $\log ($ Surplus) increases. Therefore, we find that women are significantly less likely to launch a second attempt compared to men when they exceed their goal by a significant dollar amount. As a result, this supports H4 and the humility effect - that women are less likely to pursue a second attempt relative to men, particularly when they experience substantial magnitudes of initial success. Overall, as can be seen in Figure 1, there are substantial effects on female founding rates.

\section{[Insert Tables 5a and 5b]}

[Insert Figure 1]

\section{ADDITIONAL TESTS}

We also wanted to test which effect is stronger among women. Both after a failure and after a success, the probability of launching a second project is 0.0207 lower for women compared to men, corresponding to an approximate $27 \%$ drop in probability. Therefore, women are not particularly less likely to launch again when they fail in their first attempt, compared to when they succeed. As can be seen in Table 3b, the difference in marginal 
effect of Female Creator for successful and unsuccessful projects is not statistically significant. As a result, neither effect appears to dominate.

Additionally, while we primarily consider founding rates, rather than founding success, previous research had noted that women were more likely to succeed than men in crowdfunding (Greenberg and Mollick 2015, Marom et al. 2014). We find that this also holds true in second attempts at crowdfunding. The results of a propensity score matching process for second projects (similar to that used earlier for first attempts) are outlined in Table 6, where we matched on characteristics related to both the first and second project. The means of different variables are shown for the sample of second projects before matching, and for the matched sample. Based on the t-tests of examining differences in the mean, we find that the distribution of several variables were significantly different between men and women in the unmatched sample. More specifically, we see that women were more likely than men to have succeeded in their first project, take a longer time between projects, and launch second projects with smaller goals. Moreover, while not shown in the table to conserve space, we also find significant differences in the distribution of categories between men and women. However, after matching, we find that the t-tests now reveal insignificant differences in the mean values of our project variables between men and women. Using this matched sample of second projects, we use a logit model to estimate the likelihood that the second project reaches its goal as a function of all the variables used in the matching process. The results are shown in Table 7. We find that after creating and using a matched sample of projects, that Female Creator has a positive coefficient that is significant at the $5 \%$ level. As a result, we find that women outperform men at a statistically significant level in second projects as well.

\section{[Insert Table 6] \\ [Insert Table 7]}

We also examined the relative success rate of projects where individuals persist in the face of failure. Prior theoretical literature (Hayward et al. 2006) suggests that these projects will have lower rates of success. As predicted, projects that launched despite past failures were less successful than those launched after successes. We confirm this using our model of second project performance in Table 7. In this table, we see that the indicator for first attempt success (Project Funded - First Project) is positive and highly significant. As a result, second projects 
launched after a failure are significantly less likely to reach their goal compared to second projects launched after a success.

\section{Robustness to Alternative Explanations}

Our primary analyses relied on matched samples generated using propensity score matching, wherein male and female projects were matched on several observable project attributes. While the matching process removed significant differences between the male and female subsamples along these project characteristics, additional unobserved differences across genders may actually be driving our results. More specifically, as discussed previously, the prior literature has identified a number of factors that differ between men and women and which could explain differences in entrepreneurial founding rates between the two genders. As summarized in Table 9 these factors are: preference for entrepreneurship or self-employment (e.g. Gupta et al., 2008; Shane, 2008); the necessity of entrepreneurship (e.g. Langowitz \& Minniti, 2007; Reynolds, Bygrave, Autio, Cox, \& Hay, 2002); family structure and its resulting pressures (e.g. Aldrich \& Cliff, 2003; Thebaud, 2015); human capital differences (e.g. Brush \& Hisrich, 1987; Lerner et al., 1997) the nature of social networks (e.g. Renzulli, Aldrich, \& Moody, 2000); and the ongoing success of earlier founding attempts. In order to determine whether our results are robust to accounting for such differences between men and women, we deployed a survey to measure these factors.

A stratified sample of 65,326 Kickstarter project creators were surveyed ${ }^{4}$ via email. Of those projects, 10,493 completed part of the survey $(16 \%)$ and 7,788 (12\%) completed the entire survey, these response rates are comparable with other web-based surveys in non-traditional industries within the management literature (Kriauciunas et al. 2011). Additionally, many of the email accounts were set up for completed projects and were no longer actively used, artificially lowering response rates. To provide a more accurate accounting of actual responses, open rates on emails were tracked (Nickerson 2007), with an open rate of $47.8 \%$. Open rate tracking works well for web-based email addresses (Gmail, Yahoo, Hotmail), but may not work in all cases, and could

\footnotetext{
4 The sample consisted of all projects from 2009 to May, 2015 that raised at least $\$ 1,000$ on Kickstarter. It also included half of all projects that raised between $\$ 250$ and $\$ 1000$, and $25 \%$ of projects raising under $\$ 250$.
} 
result in an underestimate of read emails. Nonetheless, using open rates suggests that overall response rates were between $16 \%$ and $33.5 \%$ of delivered email. Response rates varied by amount pledged with larger projects responding at a higher rate. After controlling for this factor, there was no significant difference between respondents and non-respondents in number of experienced backers, number of novice backers, number of other projects backed by the creator on Kickstarter, or in serial foundings by the creator.

Using the survey, we obtained complete responses for 3,685 Kickstarter projects, each of which represented the first project of a single creator. Importantly, we collected data on a number of the factors highlighted above that could account for differences in second project launch rates between genders. To measure the family structure of a creator, we recorded whether the individual was married, whether he or she had children, and the individual's age. We measured an individual's preference for self-employment using the question developed by Kolvereid (1996): "If you were to choose between running your own business and being employed by someone, what would you prefer?" Those who answered 7 (“Greatly prefer to run my own business") out of 7 on the scale were marked as having a strong preference (52.6\% of all respondents). To measure the skill and expertise of the creator, we focused on the educational background of the creator (college experience) and his or her employment status before the launch of the crowdfunding campaign. Moreover, higher degrees of success from a creator's first project may reduce the necessity of launching another one. As a result, we measured the revenue generated by the first project and the personal income of the creator since the campaign. In addition, an important performance benchmark for a crowdfunding project is whether the promised rewards were delivered on time, whether they were delivered late, or not at all. Poor delivery performance may dissuade the creator from launching a second project in the future. Therefore, we include indicators for the delivery status of the first project. Finally, in order to account for the extent to which the creator relied or benefited from a strong social network, we measured the percentage of raised funds contributed by friends and family of the project creator.

Using the aforementioned measures, we generated a matched sample of male and female projects using a similar propensity score matching to that used in earlier analysis. The first step of the matching procedure, where the gender of the creator is modeled using a logit estimator as a function of project and creator attributes, is shown in Model (1) of Table 8a. While not our primary focus, the results of this logit estimation serve as a test 
of several predictions from prior work on the differences between male and female entrepreneurs. Consistent with the arguments of prior literature, we observe that female creators are much less likely to be married and have children compared to men. Stated differently, entrepreneurs who are married and have children are more likely to be male than female. In addition, we find that when the revenue of the first project and the personal income of the creator are high, the creator is less likely to be female. While there does not appear to be any significant difference between men and women in their employment status before the campaign, we do observe that highly educated creators are more likely to be women rather than men. Furthermore, in line with prior work, creators with a strong preference for self-employment are much more likely to be male rather than female.

After male and female projects were matched along all these creator and project attributes (see Table 8b for a comparison of the unmatched and matched samples), we used this matched sample to validate our earlier analysis with the successful project subsample. In Model (2) of Table 8a, we model Second Attempt as a function of Female Creator and the other project/creator attributes. Like before, we see that Female Creator has negative coefficient that is significant at the $1 \%$ level. As a result, after generating a matched sample and controlling for several important factors highlighted by the prior literature, we continue to find that women are less likely to launch second attempts compared to men. In Model (3) of Table 8a we explore the moderating role of project surplus on the negative effect of Female Creator using this richer model. When we interact Female Creator with Log(Surplus) and compute marginal effects for Female Creator across the range of Log(Surplus) (Table 8b), we again find evidence of a negative moderating effect. Specifically, we find that the marginal effect of Female Creator grows more negative as the value of $\log ($ Surplus $)$ increases. Therefore, we continue to find that women are significantly less likely to launch a second attempt compared to men when they exceed their goal by a significant dollar amount.

[Insert Tables 8a and 8b]

[Insert Table 9]

\section{DISCUSSION AND CONCLUSION}

We hypothesized that lower female entrepreneurship rates may be partially explained by two different phenomena. On one hand, women have been found to react more rationally than men in the face of failure, suggesting that women may be less likely to engage in entrepreneurship when it is particularly risky or unlikely to 
succeed. On the other hand, women have lower levels of persistence after successful first attempts, which would lead to lower founding rates compared to men when prior experience would indicate that the chances of success are relatively high. As best summarized in Figure 1, we find strong evidence for both effects on female project creators in the context of crowdfunding.

On an individual level, this suggests that, overall, women may be more rational in their approach to entrepreneurship than men. As evidence of past failures grow, women are increasingly less likely than men to pursue second founding attempts. While this may decrease the chance of failure for women individually, it actually may hurt women as a group. If entrepreneurship is a high stakes lottery, only those who play can win. A lottery may not a good bet for individuals, but, if women disproportionately fail to enter the lottery at all than, as a group, there will be few women among successful entrepreneurs. The advantages of successful attempts, and the learning spillovers from failure (Cope 2011, Knott and Posen 2005, Shepherd 2003), will thus accrue primarily to men. Men may fail at a higher rate individually (and this is, indeed, what our data shows) but they also more likely to persist in the face of this trend towards failure, and thus make more attempts and, ultimately, found more companies. And, given the relative preference for risk, the companies that succeed may have higher returns (Dencker and Gruber 2015). Gender differences in entrepreneurship rates are therefore exacerbated as entrepreneurship trends ever more stereotypically male (Gupta et al. 2008), further reinforcing male-dominated entrepreneurial networks (Greenberg and Mollick 2014, Stuart and Sorenson 2008). This is further aggravated by the disproportionate reluctance of women with high-quality opportunities to engage in founding attempts.

If women had the same patterns of persistence as men, the effect would be large. After a failed initial attempt, $8.25 \%$ of men $(3,397$ in our original sample) make a second attempt, compared to $6.01 \%$ of women (884 in our original sample) who try again after a failure. If women had the same level of persistence in the face of failure as men, the number of total women making a second attempt after failing would increase by $37 \%-$ from 884 to 1,213. The effect on high-quality foundings is somewhat smaller but still of significant importance: if women were as likely to respond to high quality signals as men, their founding attempts after a success would increase from 1,013 to 1,326, an increase of just under 31\% in high-quality funding attempts. Taken together, these effects decrease the number of founding attempts by $25.29 \%$ compared to men. 
Theoretically, this paper contributes to the study of entrepreneurship in a number of ways. We first contribute by suggesting the importance of understanding how relative levels of persistence shape entrepreneurship. We also contribute by showing that group differences in persistence can lead to disparity in entrepreneurship rates in a population. In our case, we find a gender-based difference, but variance might also be found across cultures, classes, and geography. Differences persistence rates may play a role in explaining some long-standing gaps in entrepreneurship rates across a variety of ethnic and geographic bounds. Most directly, our findings suggests alternative explanations for the gender gap in founding rates, based on evaluation of opportunities, rather than preferences for self-employment.

Our study has a number of limitations, as well as some strengths. Projects created by women and by men exhibit differences across variety of measures, which may be the result of systematic quality differences between male and female creators willing to found projects on Kickstarter, or else among the kind of projects they create. We attempt to address these issue in both our survey and with our matched sample, both of which suggest that our results are robust to these factors, but we cannot rule out the fact that these systemic differences may account for some of our results. Also, Kickstarter represents a type of entrepreneurial action that may not generalize to other forms of entrepreneurship, though early evidence suggests that many Kickstarter projects turn into ongoing ventures (Mollick and Kuppuswamy 2014). However, a strength of the paper is that we can directly observe both second founding attempts and the previous track records, allowing us to resolve a variety of empirical challenges that have made it challenging to observe founding rates and measure entrepreneurial overconfidence.

For scholars, our research suggests a need to better understand the role of persistence in entrepreneurship. We also argue that that gender differences in founding rates can be partially explained in terms of opportunity evaluation, and not simply as a result of preference differences or structural barriers. For policy makers, our work suggests that humility may suppress high quality entrepreneurial attempts by women, and that efforts to address this issue may increase the number of successful entrepreneurs. 
REFERENCES

Agrawal, A., C. Catalini, A. Goldfarb. 2013. The Simple Economics of Crowdfunding. Policy Econ. 14 1-46.

Ai, C., E. C. Norton. 2003. Interaction terms in logit and probit models. Econ. Lett. 80(1) 123-129.

Aldrich, H., J. Cliff. 2003. The pervasive effects of family on entrepreneurship: Toward a family embeddedness perspective. J. Bus. Ventur.

Arenius, P., M. Minniti. 2005. Perceptual variables and nascent entrepreneurship. Small Bus. Econ. 24 233247.

Barber, B. M., T. Odean. 2001. Boys will be boys: Gender, overconfidence, and common stock investment. Q. J. Econ. 261-292.

Baron, R. A., M. D. Ensley. 2006. Opportunity Recognition as the Detection of Meaningful Patterns: Evidence from Comparisons of Novice and Experienced Entrepreneurs. Manage. Sci. 52(9) 1331-1344.

Beyer, S. 1990. Gender differences in the accuracy of self-evaluations of performance. J. Pers. Soc. Psychol. 59(5) 960.

Beyer, S. 1998. Gender differences in self-perception and negative recall biases. Sex Roles 38(1-2) 103-133.

Beyer, S., E. M. Bowden. 1997. Gender Differences in Seff-Perceptions: Convergent Evidence from Three Measures of Accuracy and Bias. Personal. Soc. Psychol. Bull. 23(2) 157-172.

Beyer, S., K. Rynes, J. Perrault, K. Hay, S. Haller. 2003. Gender differences in computer science students. ACM SIGCSE BUIl.

Blanch, D. C., J. A. Hall, D. L. Roter, R. M. Frankel. 2008. Medical student gender and issues of confidence. Patient Educ. Couns. 72(3) 374-381.

Bruin, A. De, C. Brush, F. Welter. 2007. Advancing a framework for coherent research on women's entrepreneurship. Entrep. Theory Pract. 31(3) 323-339.

Brush, C. G., R. D. Hisrich. 1987. Women entrepreneurs: A longitudinal study. Front. Entrep. Res. 643-653.

Busenitz, L. W., J. B. Barney. 1997. Differences between entrepreneurs and managers in large organizations: Biases and heuristics in strategic decision-making. J. Bus. Ventur. 12(1) 9-30.

Camerer, C., D. Lovallo. 1999. Overconfidence and excess entry: An experimental approach. Am. Econ. Rev. 89(1) 306-318.

Canning, J., M. Haque, Y. Wang. 2012. Women at the Wheel. New York.

Cassar, G. 2010. Are individuals entering self-employment overly optimistic? an empirical test of plans and projections on nascent entrepreneur expectations. Strateg. Manag. J. 31(8) 822-840.

Cooper, A. C., T. B. Folta, C. Woo. 1995. Entrepreneurial information search. J. Bus. Ventur. 10(2) 107-120.

Cope, J. 2011. Entrepreneurial learning from failure: An interpretative phenomenological analysis. J. Bus. Ventur. 26(6) 604-623.

Cross, S., L. Madson. 1997. Models of the self: self-construals and gender. Psychol. Bull.

Deaux, K., T. Emswiller. 1974. Explanations of successful performance on sex-linked tasks: What is skill for the male is luck for the female. J. Pers. Soc. Psychol. 29(1) 80.

Dencker, J. C., M. Gruber. 2015. The effects of opportunities and founder experience on new firm performance. Strateg. Manag. J. 36(7) 1035-1052.

Dushnitsky, G. 2009. Entrepreneurial Optimism in the Market for Technological Inventions. Organ. Sci. 21(1) 150-167. 
Eggers, J. P., L. Song. 2015. Dealing with Failure: Serial Entrepreneurs and the Costs of Changing Industries Between Ventures. Acad. Manag. J. 58(6) 1785-1803.

Fauchart, E., M. Gruber. 2011. Darwinians, Communitarians, and Missionaries: The Role of Founder Identity in Entrepreneurship. Acad. Manag. J. 54(5) 935.

Furnham, A. 2001. Self-estimates of intelligence: Culture and gender difference in self and other estimates of both general (g) and multiple intelligences. Pers. Individ. Dif.

Furnham, A., T. Hosoe, T. Tang. 2002. Male hubris and female humility? A crosscultural study of ratings of self, parental, and sibling multiple intelligence in America, Britain, and Japan. Intelligence.

Gervais, S., T. Odean. 2001. Learning to be overconfident. Rev. Financ. Stud. 14(1) 1-27.

Gimeno, J., T. B. Folta, A. C. Cooper, C. Y. Woo. 1997. Survival of the Fittest? Entrepreneurial Human Capital and the Persistence of Underperforming Firms. Adm. Sci. Q. 42(4).

Gompers, P., A. Kovner, J. Lerner. 2006. Skill vs. luck in entrepreneurship and venture capital: Evidence from serial entrepreneurs. NBER Work. Pap.

Greenberg, J., E. Mollick. 2014. Without Constraints? Representation, Homophily, and Activism in Crowdfunding.

Greenberg, J., E. R. Mollick. 2015. Leaning in or leaning on? Gender, homophily, and activism in crowdfunding. SSRN Electron. J.

Greene, P. G., C. G. Brush, M. M. Hart, P. Saparito. 2001. Patterns of venture capital funding: Is gender a factor? Ventur. Cap. 3(1) 63-83.

Grégoire, D. 2010. Cognitive processes of opportunity recognition: The role of structural alignment. Organ. Sci.

Gregoire, D. A., P. S. Barr, D. A. Shepherd. 2009. Cognitive Processes of Opportunity Recognition: The Role of Structural Alignment. Organ. Sci. 21(2) 413-431.

Gupta, V. K., A. B. Goktan, G. Gunay. 2014. Gender differences in evaluation of new business opportunity: A stereotype threat perspective. J. Bus. Ventur. 29(2) 273-288.

Gupta, V. K., D. B. Turban, N. M. Bhawe. 2008. The effect of gender stereotype activation on entrepreneurial intentions. J. Appl. Psychol. 93(5) 1053.

Haans, R. F. J., C. Pieters, Z. He. 2015. Thinking about U: Theorizing and Testing U and inverted U shaped Relationships in Strategy Research. Strateg. Manag. J.

Harrison, R., C. Mason. 2007. Does gender matter? Women business angels and the supply of entrepreneurial finance. Entrep. Theory Pract. 31(3) 445-472.

Hayward, M. L. a., D. Shepherd, D. Griffin. 2006. A Hubris Theory of Entrepreneurship. Manage. Sci. 52(2) 160-172.

Heilman, M. E., J. J. Chen. 2003. Entrepreneurship as a solution: the allure of self-employment for women and minorities. Hum. Resour. Manag. Rev. 13(2) 347-364.

Hmieleski, K. M., R. A. Baron. 2009. Entrepreneurs' optimism and new venture performance: A social cognitive perspective. Acad. Manag. J. 52(3) 473-488.

Hsu, D. 2007. Experienced entrepreneurial founders, organizational capital, and venture capital funding. Res. Policy.

Jennings, J., C. Brush. 2013. Research on women entrepreneurs: challenges to (and from) the broader 
entrepreneurship literature? Acad. Manag. Ann.

Karaca-Mandic, P., E. C. Norton, B. Dowd. 2012. Interaction terms in nonlinear models. Health Serv. Res. 47(1pt1) 255-274.

Kelley, D. J., C. G. Brush, P. G. Greene, Y. Litovsky. 2011. Global entrepreneurship monitor, 2010 report: women entrepreneurs worldwide. London Glob. Entrep. Res. Assoc.

Knight, F. 1921. Risk, uncertainty and profit H. M. Company, ed.

Knott, A., H. Posen. 2005. Is failure good. Strateg. Manag. J.

Kolvereid, L. 1996. Prediction of employment status choice intentions. Entrep. Theory Pract. 21(1) 47.

Kriauciunas, A., A. Parmigiani, M. Rivera-Santos. 2011. Leaving our comfort zone: Integrating established practices with unique adaptations to conduct survey-based strategy research in nontraditional contexts. Strateg. Manag. J. 32(9) 994-1010.

Krueger, N. 2000. The cognitive infrastructure of opportunity emergence. Entrep. Theory Pract. 24(3) 9-27. Langowitz, N., M. Minniti. 2007. The entrepreneurial propensity of women. Entrep. theory Pract. 31(3) 341364.

Lerner, M., C. Brush, R. Hisrich. 1997. Israeli women entrepreneurs: An examination of factors affecting performance. J. Bus. Ventur. 12(4) 315-339.

Lowe, R., A. Ziedonis. 2006. Overoptimism and the performance of entrepreneurial firms. Manage. Sci.

MacMillan, I. C. 1986. To really learn about entrepreneurship, let's study habitual entrepreneurs. J. Bus. Ventur. 1(1) 241-243.

Manolova, T., C. Brush, L. Edelman. 2008. What do women entrepreneurs want? Strateg. Chang.

Marom, D., A. Robb, O. Sade. 2014. Gender Dynamics in Crowdfunding (Kickstarter): Evidence on Entrepreneurs, Investors, Deals and Taste Based Discrimination. Investors, Deal. Tast. Based Discrim. (May 29, 2014).

McGrath, R. G., I. C. MacMillan. 2000. The entrepreneurial mindset: Strategies for continuously creating opportunity in an age of uncertainty. Harvard Business Press.

McMullen, J. S., D. Shepherd, A. Shepherd. 2006. Entrepreneurial action and the role of uncertainty in the theory of the entrepreneur. Acad. Manag. Rev. 31(1) 132.

Miller, D. T., M. Ross. 1975. Self-serving biases in the attribution of causality: Fact or fiction? Psychol. Bull. 82(2) 213.

Minniti, M. 2009. Gender issues in entrepreneurship.

Mollick, E. 2014. The Dynamics of Crowdfunding: Determinants of Success and Failure. J. Bus. Ventur. 29(1) $1-16$.

Mollick, E., V. Kuppuswamy. 2014. Crowdfunding: Evidence on the Democratization of Startup Funding. K. Lakhani, D. Harhoff, eds. Revolutionizing Innov. Users, Communities Openness. MIT Press.

Nickerson, D. W. 2007. Does email boost turnout. Quart. J. Polit. Sci. 2(4) 369-379.

Nieva, V. F., B. A. Gutek. 1980. Sex effects on evaluation. Acad. Manag. Rev. 5(2) 267-276.

Paik, Y. 2014. Serial Entrepreneurs and Venture Survival: Evidence from US Venture-Capital-Financed Semiconductor Firms. Strateg. Entrep. J. 8(3) 254-268.

Renzulli, L. A., H. Aldrich, J. Moody. 2000. Family matters: Gender, networks, and entrepreneurial outcomes. Soc. forces 79(2) 523-546. 
Reynolds, P. D., W. D. Bygrave, E. Autio, L. W. Cox, M. Hay. 2002. Global Entrepreneurship Monitor Executive Report 2002.

Rosenbaum, P. R. 2002. Observational studies. Springer.

Rosenbaum, P. R., D. B. Rubin. 1983. The central role of the propensity score in observational studies for causal effects. Biometrika 70(1) 41-55.

Shane, S. 2000. Prior knowledge and the discovery of entrepreneurial opportunities. Organ. Sci. 11(4) 448469.

Shane, S. 2008. The illusions of entrepreneurship: The costly myths that entrepreneurs, investors, and policy makers live by. Yale University Press.

Shane, S., S. Venkataraman. 2000. The Promise of Entrepreneurship as a Field of Research. Acad. Manag. Rev. 25(1) 217-226.

Shepherd, D. A. 2003. Learning from business failure: Propositions of grief recovery for the self-employed. Acad. Manag. Rev. 28(2) 318-328.

Simon, M., S. Houghton, K. Aquino. 2000. Cognitive biases, risk perception, and venture formation: How individuals decide to start companies. J. Bus. Ventur.

Stuart, T., O. Sorenson. 2008. Strategic networks and entrepreneurial ventures. Strateg. Entrep. J. 1(3) 211.

Thébaud, S. 2010. Gender and Entrepreneurship as a Career Choice Do Self-assessments of Ability Matter? Soc. Psychol. Q. 73(3) 288-304.

Thébaud, S. 2015. Business as Plan B Institutional Foundations of Gender Inequality in Entrepreneurship across 24 Industrialized Countries. Adm. Sci. Q. 60(4) 671-711.

Ucbasaran, D., P. Westhead, M. Wright. 2011. Why serial entrepreneurs don't learn from failure. Harv. Bus. Rev. 89(4) 26.

Verheul, I., R. Thurik, I. Grilo, P. van der Zwan. 2012. Explaining preferences and actual involvement in selfemployment: Gender and the entrepreneurial personality. J. Econ. Psychol. 33(2) 235-341.

Verheul, I., L. Uhlaner, R. Thurik. 2005. Business accomplishments, gender and entrepreneurial self-image. J. Bus. Ventur. 
Figure 1: Marginal Effect of Female Creator on Second Attempts as a Function of First Project Performance

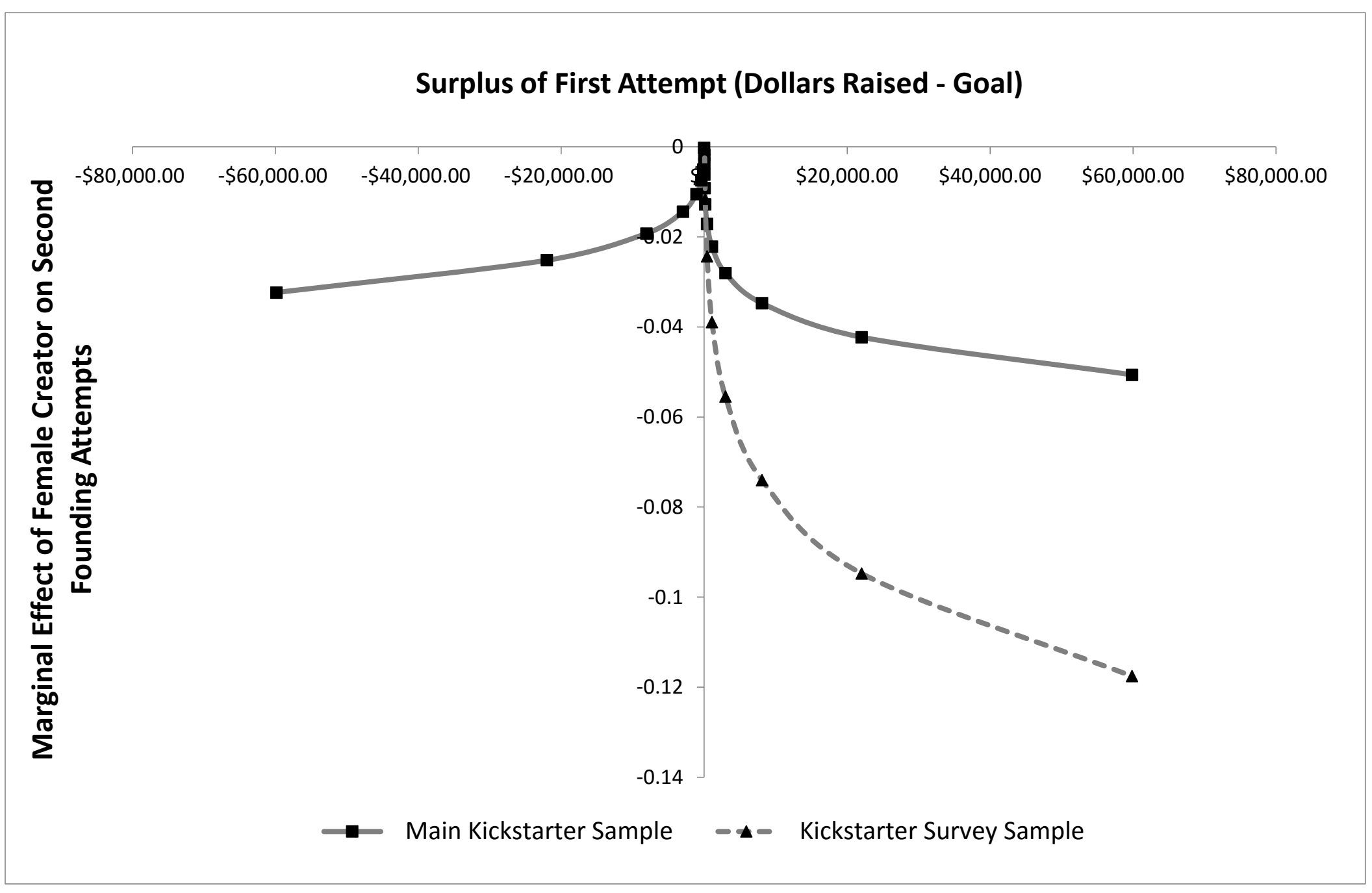


Table 1: Summary Statistics for First Project Variables

\begin{tabular}{|lrrrrrr|}
\hline Variable & $\mathrm{N}$ & Mean & Median & Std. Dev. & Min & Max \\
\hline Second Attempt & 91,054 & 0.084 & 0.000 & 0.277 & 0.000 & 1.000 \\
Female Creator & 91,054 & 0.301 & 0.000 & 0.458 & 0.000 & 1.000 \\
Project Funded & 91,054 & 0.386 & 0.000 & 0.487 & 0.000 & 1.000 \\
Goal & 91,054 & 16230.760 & 5850.000 & 33293.290 & 1000.000 & 250000.000 \\
Shortfall & 55,878 & 20744.040 & 6880.000 & 44908.010 & 20.000 & 324935.000 \\
Surplus & 35,176 & 3161.396 & 470.000 & 10439.840 & 0.000 & 80965.000 \\
Comments & 91,054 & 4.803 & 0.000 & 16.772 & 0.000 & 132.000 \\
Reward Levels & 91,054 & 9.274 & 9.000 & 4.723 & 1.000 & 27.000 \\
Words & 91,054 & 536.624 & 401.000 & 443.371 & 3.000 & 2446.000 \\
Video & 91,054 & 0.789 & 1.000 & 0.408 & 0.000 & 1.000 \\
Updates & 91,054 & 3.679 & 1.000 & 5.789 & 0.000 & 31.000 \\
\hline
\end{tabular}


Table 2: Generating Matched Samples of First Projects Using Propensity Score Matching*

\begin{tabular}{|c|c|c|c|c|c|c|}
\hline \multirow{2}{*}{ Variable } & \multicolumn{3}{|c|}{ Mean Values Before Matching } & \multicolumn{3}{|c|}{ Mean Values After Matching } \\
\hline & Female Creator $=1$ & Female Creator $=0$ & P-Value of T-Test & Female Creator $=1$ & Female Creator $=0$ & P-Value of T-Test \\
\hline
\end{tabular}

A) All First Projects (Unmatched Sample: 91,054 Projects; Matched Sample: 72,821 Projects)

\begin{tabular}{|c|c|c|c|c|c|c|}
\hline Project Funded & 0.463 & 0.353 & 0.000 & 0.463 & 0.467 & 0.332 \\
\hline Log (Goal) & 8.692 & 8.898 & 0.000 & 8.693 & 8.704 & 0.246 \\
\hline Log (Reward Levels) & 2.114 & 2.085 & 0.000 & 2.114 & 2.113 & 0.901 \\
\hline Log (Words) & 5.992 & 5.984 & 0.172 & 5.992 & 5.992 & 0.973 \\
\hline Video & 0.793 & 0.788 & 0.066 & 0.793 & 0.792 & 0.780 \\
\hline
\end{tabular}

B) Unsuccessful First Projects (Unmatched Sample: 55,878 Projects; Matched Sample: 41,926 Projects)

\begin{tabular}{|c|c|c|c|c|c|c|}
\hline Log (Shortfall) & 8.788 & 9.023 & 0.000 & 8.789 & 8.802 & 0.375 \\
\hline $\log ($ Goal $)$ & 8.913 & 9.120 & 0.000 & 8.913 & 8.924 & 0.452 \\
\hline Log (Reward Levels) & 1.979 & 1.969 & 0.066 & 1.978 & 1.980 & 0.763 \\
\hline Log (Words) & 5.861 & 5.880 & 0.016 & 5.861 & 5.859 & 0.836 \\
\hline Video & 0.700 & 0.722 & 0.000 & 0.700 & 0.699 & 0.824 \\
\hline \multicolumn{7}{|c|}{ C) Successful First Projects (Unmatched Sample: 35,176 Projects; Matched Sample: 30,806 Projects) } \\
\hline Log (Surplus) & 5.868 & 6.171 & 0.000 & 5.870 & 5.894 & 0.358 \\
\hline $\log ($ Goal $)$ & 8.436 & 8.493 & 0.000 & 8.437 & 8.455 & 0.143 \\
\hline Log (Reward Levels) & 2.271 & 2.297 & 0.000 & 2.271 & 2.276 & 0.395 \\
\hline $\log$ (Words) & 6.145 & 6.175 & 0.000 & 6.145 & 6.145 & 0.963 \\
\hline Video & 0.901 & 0.908 & 0.043 & 0.901 & 0.903 & 0.722 \\
\hline
\end{tabular}

* Projects in all three panels were also matched on binary indicators for project category, month, and year; but these were excluded from the above table to conserve space. T-tests reveal significant differences by gender in the distribution of all categories before matching. However, after matching, T-tests reveal no significant differences in category. 
Table 3a: Logit Model of Second Attempt as a Function of Female Creator

\begin{tabular}{|c|c|c|c|}
\hline & \multicolumn{3}{|c|}{$\mathrm{DV}=$ Second Attempt $(1 / 0)$} \\
\hline & (1) & (2) & (3) \\
\hline Female Creator & & $\begin{array}{c}-0.296^{* * *} \\
(0.0299)\end{array}$ & $\begin{array}{c}-0.308^{* * *} \\
(0.0425)\end{array}$ \\
\hline Female Creator X Project Funded & & & $\begin{array}{c}0.0244 \\
(0.0590)\end{array}$ \\
\hline Project Funded & $\begin{array}{c}0.0822^{* * *} \\
(0.0302)\end{array}$ & $\begin{array}{c}0.0994 * * * \\
(0.0303)\end{array}$ & $\begin{array}{c}0.0914 * * \\
(0.0361)\end{array}$ \\
\hline $\log ($ Goal $)$ & $\begin{array}{c}-0.0631 * * * \\
(0.0150)\end{array}$ & $\begin{array}{c}-0.0648^{* * *} \\
(0.0149)\end{array}$ & $\begin{array}{c}-0.0650^{* * *} \\
(0.0149)\end{array}$ \\
\hline Log(Reward Levels) & $\begin{array}{c}0.0439 \\
(0.0343)\end{array}$ & $\begin{array}{c}0.0491 \\
(0.0343)\end{array}$ & $\begin{array}{c}0.0493 \\
(0.0343)\end{array}$ \\
\hline $\log$ (Words) & $\begin{array}{c}0.0115 \\
(0.0220)\end{array}$ & $\begin{array}{c}0.0125 \\
(0.0220)\end{array}$ & $\begin{array}{c}0.0125 \\
(0.0220)\end{array}$ \\
\hline Video & $\begin{array}{c}-0.157 * * * \\
(0.0375)\end{array}$ & $\begin{array}{c}-0.156^{* * *} \\
(0.0375)\end{array}$ & $\begin{array}{c}-0.156^{* * *} \\
(0.0375)\end{array}$ \\
\hline Constant & $\begin{array}{c}-0.546^{* * *} \\
(0.188)\end{array}$ & $\begin{array}{c}-0.415^{* *} \\
(0.189)\end{array}$ & $\begin{array}{c}-0.411^{* *} \\
(0.189)\end{array}$ \\
\hline Category Fixed Effects & Yes & Yes & Yes \\
\hline Month Fixed Effects & Yes & Yes & Yes \\
\hline Year Fixed Effects & Yes & Yes & Yes \\
\hline $\mathrm{N}$ & 72,821 & 72,821 & 72,821 \\
\hline Chi-Squared & 2329.20 & 2422.03 & 2421.33 \\
\hline P-Value: Prob > Chi-Squared & 0.000 & 0.000 & 0.000 \\
\hline Pseudo R-Squared & 0.0586 & 0.0610 & 0.0610 \\
\hline
\end{tabular}

Robust standard errors in parentheses

${ }^{* * *} \mathrm{p}<0.01,{ }^{* *} \mathrm{p}<0.05, * \mathrm{p}<0.1$

Table 3b: Marginal Effects of Female Creator From Matched First Projects

\begin{tabular}{|c|c|c|}
\hline $\begin{array}{c}\text { Marginal Effect for } \\
\text { Failed Projects } \\
(1)\end{array}$ & $\begin{array}{c}\text { Marginal Effect for } \\
\text { Successful Projects } \\
(2)\end{array}$ & $\begin{array}{c}\text { Difference in } \\
\text { Marginal Effects } \\
(1)-(2)\end{array}$ \\
\hline$-0.0207 * * *$ & $-0.0207 * * *$ & 0.0000 \\
\hline
\end{tabular}


Table 4a: Logit Model of Second Attempt as a Function of Female Creator for Unsuccessful Projects

\begin{tabular}{|l|ccc|}
\hline & \multicolumn{3}{|c|}{ DV $=$ Second Attempt $(1 / 0)$} \\
& $(1)$ & $(2)$ & $(3)$ \\
\hline Female Creator & & $-0.281^{* * *}$ & 0.0262 \\
Female Creator X Log(Shortfall) & & $(0.0422)$ & $(0.307)$ \\
& & & -0.0352 \\
Log(Shortfall) & & & $(0.0348)$ \\
& $0.215^{* * *}$ & $0.204^{* * *}$ & $0.214^{* * *}$ \\
Log(Goal) & $(0.0728)$ & $(0.0733)$ & $(0.0738)$ \\
& $-0.268^{* * *}$ & $-0.260^{* * *}$ & $-0.261^{* * *}$ \\
Log(Reward Levels) & $(0.0792)$ & $(0.0796)$ & $(0.0797)$ \\
& 0.0149 & 0.0179 & 0.0180 \\
Log(Words) & $(0.0428)$ & $(0.0428)$ & $(0.0428)$ \\
& 0.0119 & 0.0125 & 0.0127 \\
Video & $(0.0281)$ & $(0.0281)$ & $(0.0281)$ \\
& $-0.145^{* * *}$ & $-0.145^{* * *}$ & $-0.144^{* * *}$ \\
Constant & $(0.0466)$ & $(0.0467)$ & $(0.0466)$ \\
& $-0.610^{* *}$ & $-0.482^{*}$ & $-0.570^{* *}$ \\
Category Fixed Effects & $(0.258)$ & $(0.259)$ & $(0.272)$ \\
Month Fixed Effects & Yes & Yes & Yes \\
Year Fixed Effects & Yes & Yes & Yes \\
& Yes & Yes & Yes \\
\hline N & & & \\
Chi-Squared & & & 41,926 \\
P-Value: Prob $>$ Chi-Squared & 1024.71 & 1060.58 & 1058.58 \\
Pseudo R-Squared & 0.000 & 0.000 & 0.000 \\
Robus standare ero & 0.0422 & 0.0443 & 0.0444 \\
\hline
\end{tabular}

Robust standard errors in parentheses

${ }^{* * *} \mathrm{p}<0.01,{ }^{* *} \mathrm{p}<0.05,{ }^{*} \mathrm{p}<0.1$

Table 4b: Marginal Effects of Female Creator from the Unsuccessful Sample of Matched First Projects

\begin{tabular}{|c|c|c|c|c|c|}
\hline \multirow{2}{*}{$\begin{array}{l}\log (\text { Shortfall }) \\
5\end{array}$} & \multirow{2}{*}{$\begin{array}{c}\text { Shortfall (\$) } \\
148.41\end{array}$} & \multicolumn{2}{|c|}{$\begin{array}{l}\text { Marginal Effect of } \\
\text { Female Creator }\end{array}$} & \multicolumn{2}{|c|}{$\begin{array}{l}\text { Difference from } \\
\text { Marginal Effect at } \\
\text { Log(Shortfall })=5\end{array}$} \\
\hline & & -0.0051 & & & \\
\hline 6 & 403.43 & -0.0074 & $*$ & -0.0023 & $* * *$ \\
\hline 7 & $1,096.63$ & -0.0105 & $* * *$ & -0.0054 & $* * *$ \\
\hline 8 & $2,980.96$ & -0.0144 & $* * *$ & -0.0093 & $* * *$ \\
\hline 9 & 8,103.08 & -0.0193 & $* * *$ & -0.0142 & $* * *$ \\
\hline 10 & $22,026.47$ & -0.0252 & $* * *$ & -0.0201 & $* * *$ \\
\hline 11 & $59,874.14$ & -0.0324 & $* * *$ & -0.0273 & $* *$ \\
\hline
\end{tabular}


Table 5a: Logit Model of Second Attempt as a Function of Female Creator for Successful Projects

\begin{tabular}{|c|c|c|c|}
\hline & \multicolumn{3}{|c|}{$\mathrm{DV}=$ Second Attempt $(1 / 0)$} \\
\hline & (1) & (2) & (3) \\
\hline \multirow[t]{2}{*}{ Female Creator } & & $-0.232 * * *$ & -0.00682 \\
\hline & & $(0.0439)$ & $(0.156)$ \\
\hline \multirow[t]{2}{*}{ Female Creator X Log(Surplus) } & & & -0.0366 \\
\hline & & & $(0.0244)$ \\
\hline \multirow[t]{2}{*}{ Log(Surplus) } & $0.162^{* * *}$ & $0.160^{* * *}$ & $0.172^{* * *}$ \\
\hline & $(0.0133)$ & $(0.0132)$ & $(0.0158)$ \\
\hline \multirow[t]{2}{*}{$\log ($ Goal $)$} & $-0.299 * * *$ & $-0.298^{* * *}$ & $-0.299 * * *$ \\
\hline & $(0.0274)$ & $(0.0274)$ & $(0.0274)$ \\
\hline \multirow[t]{2}{*}{ Log(Reward Levels) } & $0.237 * * *$ & $0.240 * * *$ & $0.241 * * *$ \\
\hline & $(0.0605)$ & $(0.0603)$ & $(0.0603)$ \\
\hline \multirow[t]{2}{*}{$\log ($ Words $)$} & -0.0309 & -0.0283 & -0.0291 \\
\hline & $(0.0358)$ & $(0.0357)$ & $(0.0357)$ \\
\hline \multirow[t]{2}{*}{ Video } & -0.0300 & -0.0277 & -0.0264 \\
\hline & $(0.0699)$ & $(0.0699)$ & $(0.0699)$ \\
\hline \multirow[t]{2}{*}{ Constant } & $0.643^{* *}$ & $0.746^{* * *}$ & $0.674^{* *}$ \\
\hline & $(0.281)$ & $(0.281)$ & $(0.285)$ \\
\hline Category Fixed Effects & Yes & Yes & Yes \\
\hline Month Fixed Effects & Yes & Yes & Yes \\
\hline Year Fixed Effects & Yes & Yes & Yes \\
\hline $\mathrm{N}$ & 30,806 & 30,806 & 30,806 \\
\hline Chi-Squared & 1587.79 & 1611.21 & 1616.06 \\
\hline P-Value: Prob $>$ Chi-Squared & 0.000 & 0.000 & 0.000 \\
\hline Pseudo R-Squared & 0.103 & 0.105 & 0.105 \\
\hline
\end{tabular}

Robust standard errors in parentheses

*** $\mathrm{p}<0.01,{ }^{* *} \mathrm{p}<0.05, * \mathrm{p}<0.1$

Table 5b: Marginal Effects of Female Creator from the Successful Sample of Matched First Projects

\begin{tabular}{|c|c|c|c|c|c|}
\hline Log(Surplus) & Surplus (\$) & \multicolumn{2}{|c|}{$\begin{array}{l}\text { Marginal Effect of } \\
\text { Female Creator }\end{array}$} & \multicolumn{2}{|c|}{$\begin{array}{l}\text { Difference from } \\
\text { Marginal Effect at } \\
\text { Log(Surplus })=0\end{array}$} \\
\hline 0 & 1.00 & -0.0002 & & & \\
\hline 1 & 2.72 & -0.0018 & & & \\
\hline 2 & 7.39 & -0.0037 & & & \\
\hline 3 & 20.09 & -0.0062 & & & \\
\hline 4 & 54.60 & -0.0092 & $* *$ & -0.0089 & $* * *$ \\
\hline 5 & 148.41 & -0.0128 & $* * *$ & -0.0126 & $* * *$ \\
\hline 6 & 403.43 & -0.0171 & $* * *$ & -0.0169 & $* * *$ \\
\hline 7 & $1,096.63$ & -0.0222 & $* * *$ & -0.0219 & $* * *$ \\
\hline 8 & $2,980.96$ & -0.0281 & $* * *$ & -0.0278 & $* * *$ \\
\hline 9 & $8,103.08$ & -0.0348 & $* * *$ & -0.0345 & $* * *$ \\
\hline 10 & $22,026.47$ & -0.0423 & $* * *$ & -0.0420 & $* * *$ \\
\hline 11 & $59,874.14$ & -0.0506 & $* * *$ & -0.0504 & $* * *$ \\
\hline
\end{tabular}


Table 6: Matched Sample of Second Projects*

\begin{tabular}{|c|c|c|c|c|c|c|}
\hline \multirow{2}{*}{ Variable } & \multicolumn{3}{|c|}{ Mean Values Before Matching $(\mathrm{N}=7,367)$} & \multicolumn{3}{|c|}{ Mean Values After Matching $(\mathrm{N}=5,200)$} \\
\hline & Female Creator $=1$ & Female Creator $=0$ & P-Value of T-Test & Female Creator $=1$ & Female Creator $=0$ & P-Value of T-Test \\
\hline Project Funded - First Project & 0.579 & 0.439 & 0.000 & 0.578 & 0.588 & 0.523 \\
\hline Percent Goal Change & 1.566 & 1.363 & 0.141 & 1.560 & 1.523 & 0.835 \\
\hline Category Change & 0.220 & 0.223 & 0.769 & 0.220 & 0.229 & 0.495 \\
\hline Log (Days Between Projects) & 5.190 & 5.059 & 0.001 & 5.190 & 5.191 & 0.974 \\
\hline Duration & 33.871 & 34.286 & 0.241 & 33.846 & 33.361 & 0.270 \\
\hline $\log ($ Goal $)$ & 8.466 & 8.646 & 0.000 & 8.467 & 8.500 & 0.354 \\
\hline Log (Reward Levels) & 2.207 & 2.188 & 0.169 & 2.207 & 2.207 & 0.975 \\
\hline Log (Words) & 6.092 & 6.121 & 0.179 & 6.092 & 6.098 & 0.794 \\
\hline Video & 0.816 & 0.815 & 0.854 & 0.816 & 0.823 & 0.607 \\
\hline
\end{tabular}

* Projects were also matched on binary indicators for project category, month, and year; but these were excluded from the above table to conserve space. T-tests reveal significant differences by gender in the distribution of most categories before matching. However, after matching, T-tests reveal no significant differences in category. 
Table 7: Logit Model of Second Project Success as a Function of Female Creator

\begin{tabular}{|c|c|c|}
\hline & $\mathrm{DV}=$ Seconc & Funded $(1 / 0)$ \\
\hline & (1) & (2) \\
\hline Female Creator & & $0.175^{* *}$ \\
\hline & & $(0.0752)$ \\
\hline Project Funded - First Project & $1.944^{* * *}$ & $1.937 * * *$ \\
\hline & $(0.0813)$ & $(0.0814)$ \\
\hline Percent Goal Change & $-0.0576 * * *$ & $-0.0580 * * *$ \\
\hline & $(0.00923)$ & $(0.00921)$ \\
\hline Category Change & $-0.483^{* * *}$ & $-0.482 * * *$ \\
\hline & $(0.0882)$ & $(0.0884)$ \\
\hline Log (Days Between Projects) & $0.117 * * *$ & $0.117 * * *$ \\
\hline & $(0.0298)$ & $(0.0298)$ \\
\hline $\log$ (Goal) & $-0.459 * * *$ & $-0.458^{* * *}$ \\
\hline & $(0.0397)$ & $(0.0397)$ \\
\hline Log (Reward Levels) & $0.945^{* * *}$ & $0.940^{* * *}$ \\
\hline & $(0.0902)$ & $(0.0902)$ \\
\hline Log (Words) & $0.482 * * *$ & $0.481 * * *$ \\
\hline & $(0.0542)$ & $(0.0541)$ \\
\hline Video & $0.548^{* * *}$ & $0.551 * * *$ \\
\hline & $(0.102)$ & $(0.102)$ \\
\hline Duration & $-0.0176^{* * *}$ & $-0.0177 * * *$ \\
\hline & $(0.00300)$ & $(0.00300)$ \\
\hline Constant & -1.036 & -1.135 \\
\hline & $(0.739)$ & $(0.737)$ \\
\hline Category Fixed Effects & Yes & Yes \\
\hline Month Fixed Effects & Yes & Yes \\
\hline Year Fixed Effects & Yes & Yes \\
\hline $\mathrm{N}$ & 5,200 & 5,200 \\
\hline Chi-Squared & 1394.68 & 1397.19 \\
\hline P-Value: Prob > Chi-Squared & 0.000 & 0.000 \\
\hline Pseudo R-Squared & 0.307 & 0.307 \\
\hline
\end{tabular}

Robust standard errors in parentheses

${ }^{* * *} \mathrm{p}<0.01,{ }^{* *} \mathrm{p}<0.05,{ }^{*} \mathrm{p}<0.1$ 
Table 8a: Matched Sample Analysis of Second Attempts as a Function of Female Creator (Using Kickstarter Survey Sample)

\begin{tabular}{|c|c|c|c|}
\hline \multirow{3}{*}{ VARIABLES } & \multirow{3}{*}{$\begin{array}{c}\text { DV = Female Creator } \\
\text { Full Sample } \\
(1)\end{array}$} & \multirow{2}{*}{\multicolumn{2}{|c|}{$\begin{array}{c}\mathrm{DV}=\text { Second Attempt }(1 / 0) \\
\text { Matched Sample }\end{array}$}} \\
\hline & & & \\
\hline & & $(2)$ & (3) \\
\hline Female Creator & & $\begin{array}{c}-0.344^{* *} \\
(0.136)\end{array}$ & $\begin{array}{c}0.533 \\
(0.492)\end{array}$ \\
\hline Female X Log (Surplus) & & & $\begin{array}{l}-0.141 * \\
(0.0757)\end{array}$ \\
\hline Log (Surplus) & $\begin{array}{l}-0.0114 \\
(0.0208)\end{array}$ & $\begin{array}{l}0.110^{* *} \\
(0.0446)\end{array}$ & $\begin{array}{c}0.163^{* * *} \\
(0.0565)\end{array}$ \\
\hline $\log ($ Goal $)$ & $\begin{array}{c}0.109 * * * \\
(0.0380)\end{array}$ & $\begin{array}{c}-0.284^{* * *} \\
(0.0695)\end{array}$ & $\begin{array}{c}-0.284 * * * \\
(0.0688)\end{array}$ \\
\hline \multicolumn{4}{|l|}{ Video } \\
\hline \multicolumn{4}{|l|}{ Family Structure } \\
\hline Age & $\begin{array}{c}0.00521 \\
(0.00397)\end{array}$ & $\begin{array}{c}0.00304 \\
(0.00717)\end{array}$ & $\begin{array}{c}0.00243 \\
(0.00712)\end{array}$ \\
\hline Children & $\begin{array}{c}-0.276^{* * *} \\
(0.0933)\end{array}$ & $\begin{array}{l}0.0639 \\
(0.159)\end{array}$ & $\begin{array}{l}0.0704 \\
(0.159)\end{array}$ \\
\hline Married & $\begin{array}{c}-0.275^{* * *} \\
(0.0881)\end{array}$ & $\begin{array}{l}0.253^{*} \\
(0.150)\end{array}$ & $\begin{array}{l}0.260^{*} \\
(0.150)\end{array}$ \\
\hline \multicolumn{4}{|l|}{ Necessity } \\
\hline$(\$ 0, \$ 1000]$ & $\begin{array}{c}0.00870 \\
(0.100)\end{array}$ & $\begin{array}{c}0.459 * * \\
(0.183)\end{array}$ & $\begin{array}{c}0.468 * * \\
(0.182)\end{array}$ \\
\hline$(\$ 1000, \$ 10000]$ & $\begin{array}{l}-0.119 \\
(0.106)\end{array}$ & $\begin{array}{l}0.366^{*} \\
(0.190)\end{array}$ & $\begin{array}{c}0.378^{* *} \\
(0.189)\end{array}$ \\
\hline$(\$ 10000)$, & $\begin{array}{c}-0.287^{* *} \\
(0.140)\end{array}$ & $\begin{array}{l}0.427^{*} \\
(0.236)\end{array}$ & $\begin{array}{l}0.429 * \\
(0.238)\end{array}$ \\
\hline Log (Personal income after project) & $\begin{array}{c}-0.331 * * * \\
(0.0411)\end{array}$ & $\begin{array}{l}-0.142^{*} \\
(0.0746)\end{array}$ & $\begin{array}{l}-0.144^{*} \\
(0.0746)\end{array}$ \\
\hline \multicolumn{4}{|l|}{ Skill/Expertise } \\
\hline \multicolumn{4}{|l|}{ Educational Background } \\
\hline College Graduate & $\begin{array}{c}0.269 * * \\
(0.111)\end{array}$ & $\begin{array}{l}0.0284 \\
(0.203)\end{array}$ & $\begin{array}{l}0.0409 \\
(0.203)\end{array}$ \\
\hline Post-Graduate Degree & $\begin{array}{c}0.610^{* * *} \\
(0.117)\end{array}$ & $\begin{array}{c}0.110 \\
(0.219)\end{array}$ & $\begin{array}{c}0.103 \\
(0.219)\end{array}$ \\
\hline \multicolumn{4}{|l|}{ Prior Employment Status (Ref: Unemployed) } \\
\hline Paid Employment & $\begin{array}{l}-0.253 \\
(0.173)\end{array}$ & $\begin{array}{l}0.737^{*} \\
(0.431)\end{array}$ & $\begin{array}{l}0.747 * \\
(0.432)\end{array}$ \\
\hline Entrepreneur or otherwise self-employed & $\begin{array}{c}0.160 \\
(0.171)\end{array}$ & $\begin{array}{c}0.996^{* *} \\
(0.423)\end{array}$ & $\begin{array}{c}1.008^{* *} \\
(0.424)\end{array}$ \\
\hline
\end{tabular}




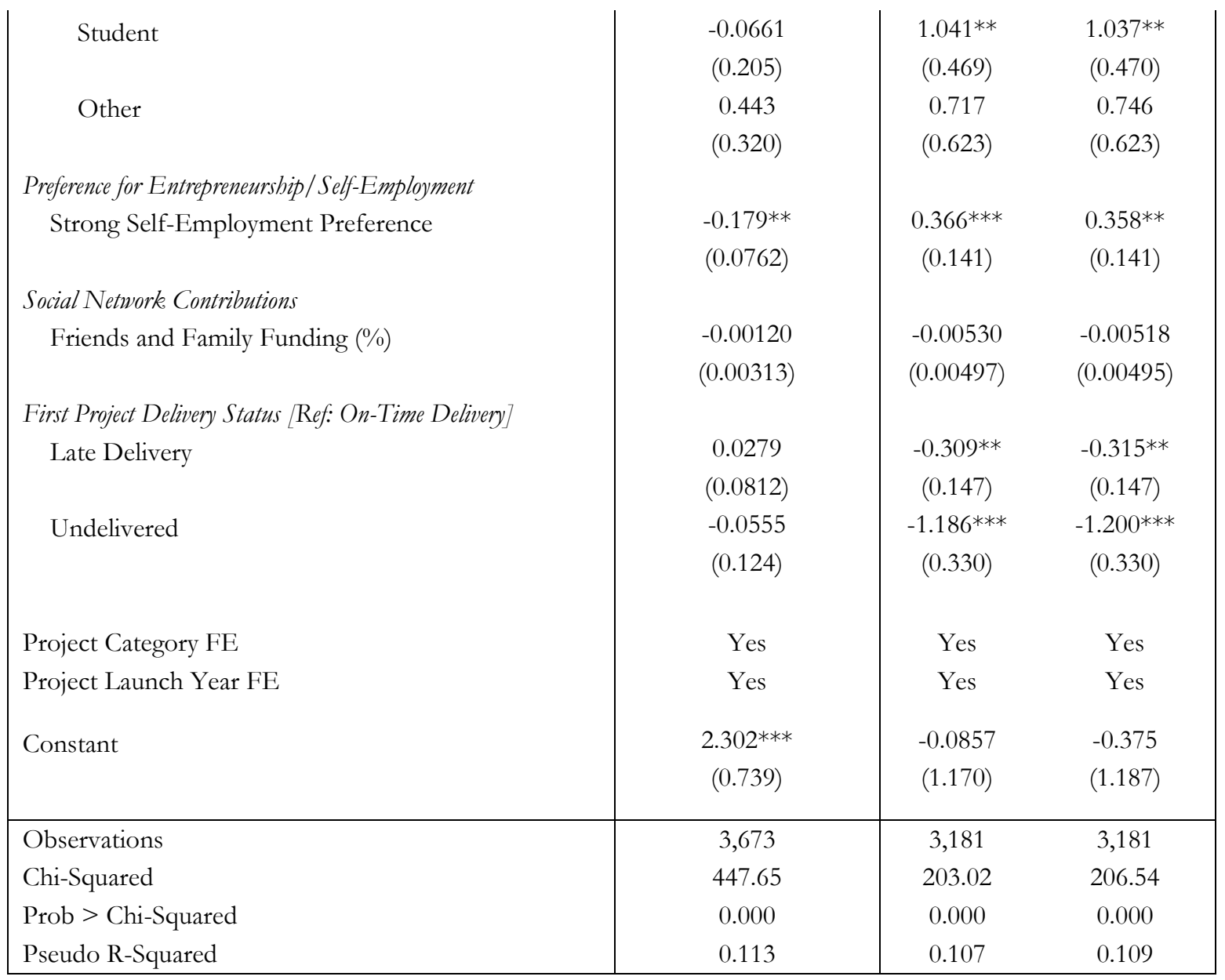

Robust standard errors in parentheses

*** $\mathrm{p}<0.01,{ }^{* *} \mathrm{p}<0.05,{ }^{*} \mathrm{p}<0.1$ 
Table 8b: Matched Sample of First Projects from Kickstarter Survey Data

\begin{tabular}{|c|c|c|c|c|c|c|}
\hline \multirow{2}{*}{ Variable } & \multicolumn{3}{|c|}{ Mean Values Before Matching $(\mathrm{N}=7,367)$} & \multicolumn{3}{|c|}{ Mean Values After Matching $(\mathrm{N}=3,168)$} \\
\hline & Female Creator $=1$ & Female Creator $=0$ & $\begin{array}{c}\text { P-Value of } \\
\text { T-Test }\end{array}$ & Female Creator $=1$ & Female Creator $=0$ & $\begin{array}{c}\text { P-Value of } \\
\text { T-Test }\end{array}$ \\
\hline Log (Surplus) & 5.994 & 6.426 & 0.000 & 5.997 & 5.987 & 0.891 \\
\hline Log (Goal) & 8.288 & 8.337 & 0.200 & 8.287 & 8.306 & 0.648 \\
\hline Video & 0.885 & 0.910 & 0.012 & 0.885 & 0.891 & 0.604 \\
\hline Age & 37.900 & 38.019 & 0.751 & 37.890 & 37.384 & 0.223 \\
\hline Children & 0.314 & 0.418 & 0.000 & 0.314 & 0.283 & 0.062 \\
\hline Married & 0.427 & 0.549 & 0.000 & 0.428 & 0.424 & 0.833 \\
\hline \multicolumn{7}{|l|}{ Revenue of Project: } \\
\hline$(\$ 0, \$ 1000]$ & 0.289 & 0.270 & 0.203 & 0.290 & 0.283 & 0.681 \\
\hline$(\$ 1000, \$ 10000]$ & 0.235 & 0.254 & 0.171 & 0.235 & 0.243 & 0.617 \\
\hline$(\$ 10000)$, & 0.120 & 0.167 & 0.000 & 0.120 & 0.123 & 0.813 \\
\hline Log (Personal income after project) & 10.270 & 10.635 & 0.000 & 10.273 & 10.257 & 0.648 \\
\hline \multicolumn{7}{|l|}{ Educational Background: } \\
\hline College Graduate & 0.481 & 0.517 & 0.030 & 0.482 & 0.499 & 0.350 \\
\hline Post-Graduate Degree & 0.388 & 0.309 & 0.000 & 0.387 & 0.371 & 0.364 \\
\hline \multicolumn{7}{|l|}{ Prior Employment Status: } \\
\hline Paid Employment & 0.333 & 0.443 & 0.000 & 0.333 & 0.322 & 0.524 \\
\hline Entrepreneur/self-employed & 0.479 & 0.406 & 0.000 & 0.478 & 0.469 & 0.592 \\
\hline Student & 0.025 & 0.015 & 0.035 & 0.025 & 0.029 & 0.519 \\
\hline Other & 0.105 & 0.090 & 0.118 & 0.105 & 0.125 & 0.088 \\
\hline Strong Self-Employment Preference & 0.507 & 0.538 & 0.068 & 0.507 & 0.498 & 0.611 \\
\hline Friends and Family Funding (\%) & 62.746 & 52.475 & 0.000 & 62.690 & 62.779 & 0.933 \\
\hline \multicolumn{7}{|l|}{ First Project Delivery Status: } \\
\hline Late Delivery & 0.382 & 0.401 & 0.248 & 0.383 & 0.395 & 0.474 \\
\hline Undelivered & 0.129 & 0.138 & 0.407 & 0.129 & 0.124 & 0.662 \\
\hline
\end{tabular}

* Projects were also matched on binary indicators for project category and year of project launch; but these were excluded from the above table to conserve space. T-tests reveal significant differences by gender in the distribution of most categories before matching. However, after matching, T-tests reveal no significant differences in category. 
Table 9: Summary of results from Table 8.

\begin{tabular}{|c|c|c|c|}
\hline Factor & $\begin{array}{l}\text { Examples of } \\
\text { prior literature } \\
\text { on gender and } \\
\text { entrepreneurship } \\
\text { involving this } \\
\text { factor }\end{array}$ & $\begin{array}{l}\text { How do women and men } \\
\text { differ in the sample? }\end{array}$ & $\begin{array}{l}\text { Are there effects on becoming a } \\
\text { serial founder? (using the matched } \\
\text { sample and all controls) }\end{array}$ \\
\hline $\begin{array}{l}\text { Persistence } \\
\text { (Female x surplus) }\end{array}$ & This paper & $\mathrm{N} / \mathrm{A}$ & $\begin{array}{l}\text { Yes. The larger the degree of success, } \\
\text { the less likely that women (compared } \\
\text { to men) will become serial founders }\end{array}$ \\
\hline $\begin{array}{l}\text { Family obligations } \\
\text { (Marital status, } \\
\text { children, age) }\end{array}$ & $\begin{array}{l}\text { Aldrich \& Cliff, } \\
\text { 2003; Thebaud, } \\
2015\end{array}$ & $\begin{array}{l}\text { As suggested in the } \\
\text { literature, successful first- } \\
\text { time female founders are less } \\
\text { likely to have children or to } \\
\text { have married. }\end{array}$ & Not in matched sample. \\
\hline $\begin{array}{l}\text { Necessity } \\
\text { (Amount of } \\
\text { additional revenue } \\
\text { generated by first } \\
\text { project, personal } \\
\text { income after first } \\
\text { project) }\end{array}$ & $\begin{array}{l}\text { Langowitz \& } \\
\text { Minniti, 2007; } \\
\text { Reynolds et al., } \\
2002\end{array}$ & $\begin{array}{l}\text { Successful first-time female } \\
\text { founders have lower income } \\
\text { after their first success, and } \\
\text { are less likely to have } \\
\text { generated over } \$ 10,000 \text { in } \\
\text { revenue. }\end{array}$ & $\begin{array}{l}\text { Some. Increased personal income } \\
\text { lowers the chance of second attempts, } \\
\text { projects that generated less than } \\
\$ 1,000 \text { in revenue increased the } \\
\text { chance of second attempts }\end{array}$ \\
\hline $\begin{array}{l}\text { Human capital } \\
\text { (Education level, } \\
\text { prior employment } \\
\text { status, prior } \\
\text { entrepreneurial } \\
\text { experience) }\end{array}$ & $\begin{array}{l}\text { Brush \& Hisrich, } \\
\text { 1987; Lerner et al., } \\
1997\end{array}$ & $\begin{array}{l}\text { Successful first-time female } \\
\text { founders are more likely to } \\
\text { be college graduates, and to } \\
\text { have post-graduate degrees. }\end{array}$ & $\begin{array}{l}\text { Some. Only from the founder's prior } \\
\text { job being entrepreneur, which } \\
\text { increases chance of second attempts. }\end{array}$ \\
\hline $\begin{array}{l}\text { Preference for } \\
\text { entrepreneurship }\end{array}$ & $\begin{array}{l}\text { Gupta et al., 2008; } \\
\text { Shane, } 2008\end{array}$ & $\begin{array}{l}\text { Women have lower } \\
\text { preference for } \\
\text { entrepreneurship. }\end{array}$ & $\begin{array}{l}\text { Yes. Preference for entrepreneurship } \\
\text { is associated with higher chances of } \\
\text { second attempts }\end{array}$ \\
\hline $\begin{array}{l}\text { Social network } \\
\text { support }\end{array}$ & $\begin{array}{l}\text { Renzulli, Aldrich, } \\
\text { \& Moody, } 2000\end{array}$ & $\begin{array}{l}\text { Women receive more } \\
\text { donations from friends and } \\
\text { family than men, but the } \\
\text { amount of those donations } \\
\text { do not differ }\end{array}$ & Not in matched sample \\
\hline $\begin{array}{l}\text { Successful } \\
\text { completion of first } \\
\text { project }\end{array}$ & $\begin{array}{l}\text { None on gender, } \\
\text { but see Gompers } \\
\text { et al., } 2006\end{array}$ & No difference & $\begin{array}{l}\text { Yes. Failures to complete first project } \\
\text { decrease the chance of becoming a } \\
\text { serial founder. }\end{array}$ \\
\hline
\end{tabular}

